\title{
"White People Still Come Out on Top": The Persistence of White Supremacy in Shaping Coloured South Africans' Perceptions of Racial Hierarchy and Experiences of Racism in Post-Apartheid South Africa
}

\author{
Whitney N. Laster Pirtle $\mathbb{C}$
}

\section{check for}

Citation: Pirtle, Whitney N. Laster. 2022. “White People Still Come Out on Top": The Persistence of White Supremacy in Shaping Coloured South Africans' Perceptions of Racial Hierarchy and Experiences of Racism in Post-Apartheid South Africa. Social Sciences 11: 70. https:// doi.org/10.3390/socsci11020070

Academic Editors: David L. Brunsma and Jennifer Sims

Received: 19 October 2021 Accepted: 7 February 2022 Published: 14 February 2022

Publisher's Note: MDPI stays neutral with regard to jurisdictional claims in published maps and institutional affiliations.

Copyright: (C) 2022 by the author. Licensee MDPI, Basel, Switzerland. This article is an open access article distributed under the terms and conditions of the Creative Commons Attribution (CC BY) license (https:// creativecommons.org/licenses/by/ $4.0 /)$
Department of Sociology, University of California Merced, Merced, CA 95343, USA; wpirtle@ucmerced.edu

\begin{abstract}
White supremacy shaped both the formation of the South African racial state and the formation of racial groups, including the creation of the Coloured category as mixed and liminal between White and Black. There are, however, debates about the continuing legacy of white supremacy in postapartheid, contemporary South Africa. This paper joins others in the important task of delineating racial hierarchies within contemporary South African society to help reveal the form of oppression, and the accompanying underlying assumptions and ideologies, such as white supremacy, that allows racial difference and deprivation to remain. In this paper, I analyze semi-structured interview data from 50 "Coloured" adults in order to explore their understanding of white supremacy, the racial hierarchy, and contemporary racism. I find that white supremacy negatively impacts Coloureds' lived experiences through shaping their experiences of structural and interpersonal discrimination from White South Africans. In addition, Coloured South Africans understand the legacy of white supremacy in shaping contemporary racial hierarchies such that White South Africans "still come out on top." However, I argue that, at the same time, white supremacy also "colours" or hinders some Coloured respondents' perceptions of their remaining relative privilege in post-apartheid South Africa. This project contributes by revealing a more complete story about the pervasiveness of contemporary hegemonic, global white supremacy that impacts all aspects of the racial hierarchy, including those mixed or in the middle.
\end{abstract}

Keywords: coloured South Africans; white supremacy; racial hierarchy; racial discrimination

\section{Introduction}

Despite hopes for the so-called new South Africa to be a non-racial and non-racist nation, contemporary research typically confirms that the legacy of white supremacy manifests in post-apartheid South Africa today, with economic inequality growing across and within racial groups (Neff 2007; Nattrass and Seekings 2001; Seekings and Nattrass 2005). For example, a report on "White vs. Black Unemployment in South Africa" (BusinessTech 2015) revealed by 2014 , nearly $30 \%$ of the Black/African ${ }^{1}$ population remained unemployed and had the highest within-group proportion (30\%) of workers employed in low skilled work. That same year the unemployment rate was only $7.3 \%$ for White South Africans, and only $5 \%$ of members of this group worked low-skilled jobs. The data supporting White South Africans' continued grasp over economic resources well into the post-apartheid era is often put into conversation with statistics showing that the number of Blacks in the middle class more than doubled from the 1990s (BusinessTech 2015), leading to complicated interpretations of contemporary dynamics as being characterized by both sustained White dominance as well as impressive Black growth. Some go as far as to refute the within racial group disparities by highlighting the rise in a Black South African political and economic elite as a counterpoint to claims of enduring and systemic racism (Bhorat and van der Westhuizen 2008). In addition to the variety of interpretations of these economic statistics, 
research on the ground suggests both White and Black South Africans are discontent with contemporary racial hierarchies. For example, White South Africans perceive slippage from their position of power and are resentful of racial redress legislation (Dolby 2001), while Black South Africans still perceive a lack of opportunities to obtain power and resources (Silva 2012). Overall, both objective and perceptive understandings of South Africa's changing hierarchies are multifaceted and complex.

Some intriguing statistics that are less discussed among the mix of Black and White dynamics is that although unemployment in South Africa increased overall from 2008 to 2014, the largest increase was actually tracked among Coloured South Africans. In 2014, the unemployment rate was $24 \%$ for Coloured South Africans (up from 19\% in 2008), with close to the same proportion (30\%) of Coloured as Black workers employed in low-skill jobs (BusinessTech 2015). Often, assessments by Coloured South Africans of contemporary economic and racial dynamics are also left out of the conversation.

This paper explores perceptions of white supremacy, the racial hierarchy, and contemporary racism in the new South Africa by interrogating claims among Coloured South Africans. The Coloured group is often considered a mixed-race or creolized group in South Africa, with origins in racial mixing dating back to colonial conquest in the 1600 s, but the category includes indigenous groups, such as the Khoi and San people, as well as other groups unable to fit into categories of White and Black (Adhikari 2005; Laster Pirtle 2021; Lewis 1987). Many argue that the Coloured racial category served as a buffering group between Whites and Blacks / Africans during the rigidly racist apartheid state (e.g., Lewis 1987). However, even within the transition from the overtly racist apartheid nation to the democratic, South African rainbow nation, some argue that the Coloured racial category continues to take meaning by signifying being neither Black nor White (Adhikari 2005; Adhikari 2006; Erasmus 2001).

Yet, there is limited research on Coloureds' experiences and perceptions in contemporary South Africa. This is a limitation to the field, as I argue the perceptions of racial hierarchy and racism from Coloured South Africans' perspective are informative about racial tensions between all groups in the new South Africa. Moreover, delineating racial hierarchies within a particular racialized society is an essential task because it can reveal underlying ideologies, such as white supremacy, that allow racial difference and deprivation to exist. I intervene by analyzing semi-structured interview data from 50 "Coloured" adults. I explore their understanding of racial hierarchy, experiences of white racial discrimination, and attitudes towards White South Africans. I find that white supremacy negatively impacts Coloured South Africans' lived experiences, but argue that, at the same time, white supremacy also "colours" some Coloureds' own understanding (or not) of their remaining relative privilege compared to Black South Africans in post-apartheid South Africa. This project contributes to better understanding white supremacy globally by focusing on its impact on mixed-race and other racially liminal groups, revealing a more complete story about the pervasiveness of contemporary hegemonic, global white supremacy that impacts all aspects of the racial hierarchy.

\section{Background}

\subsection{White Supremacy and the Construction of Coloured before and during Apartheid South Africa}

The formation of South Africa was grounded in beliefs of white supremacy (Cell 1982; Fredrickson 1981; Marx 1998; Winant 2001), which refers to the hegemonic, ideological force supporting White dominance over non-White populations. White supremacy tied together various practices, laws, and institutions to form the South African nation-state, and importantly, form the structure of South Africa's racial hierarchy. It was white supremacist ideology that initially led Dutch traders to occupy land and peoples at the Southern tip of Africa in 1652, set forth South Africa's colonial history, and sustained centuries of exploitation and extraction leading up to the formation of the Union of South Africa in 1902. Moreover, as Clark and Worger remark, through legal racial discrimination practices at the turn of the twentieth century, South Africa showed "[a] commitment to segregation and 
to institutionalizing white supremacy on a national basis underpinned the establishment" (Clark and Worger 2016).

Apartheid rule in South Africa-what was known as the "highest stage of White supremacy" (Cell 1982)—came about shortly after the forming of the republic in 1948. The White-led National Party gained popularity for its promise to uphold the racial lines and swiftly brought forth a herrenvolk democracy to South Africa (van der Berge 1967). The National Party did so through implementing apartheid laws based on racial separateness, with the ultimate goal of removing Black Africans from the state (Clark and Worger 2016). Through this envisioning and legal legitimizing of racial separateness, MacDonald (2006) argues that "the White supremacist state made communities of "White" and "Blacks" by conferring citizenship on one and denying the other" (pp. 3-4).

White supremacy, though, must also be included as a factor shaping the racial formation of Coloured South Africans. Moreover, the mix between two unequal status groups resulted in a population of offspring that was set apart and between the thought to be superior European Whites and the subjugated Blacks/Africans. This racial project then rendered Coloured as neither of those things, but considered liminal, marginal, mixed, and creolized (Adhikari 2005; Erasmus 2017; Lewis 1987).

Racial hybridity, as described by Adhikari (2006), was indeed considered a bedrock to the Coloured classification. However, the Coloured racial category also includes those with ancestral roots directly linked to the earliest African inhabitants, such as the Khoisan peoples, including San, Bush, and Khoi hunter-gatherer clans (Bestman 2009). This larger amalgam also includes Malays (a primarily Muslim community that resulted from migration from India and miscegenation with others in the Cape), Griquas (a heterogeneous community that secluded themselves to create a sense of common solidarity), and other groups that did not fit into White or Black (see, Adhikari 2005; Lewis 1987). Thus, leading up to and during apartheid South Africa, Coloureds began to solidify a group separate from but between White and Black. Indian and Asian South Africans also later fulfilled a similar buffering role (see, Bonacich 1973).

Indeed, white supremacy shaped the racial hierarchy in South Africa to the highest degree not only by naming and separating groups but also by organizing access to opportunities, resources, and status. Seekings and Nattrass (2005) describe this structure such that: "white people occupy[ed] the higher positions in the division of labor and African people occupy[ed] the bottom positions, Coloured and Indian people filled intermediate positions. This racial hierarchy was especially clear in Cape Town, with its substantial Coloured population and especially strict controls on the influx of Africans" (Seekings and Nattrass 2005, p. 65). In sum, apartheid institutionalized white supremacy such that the racial hierarchy in apartheid South Africa was concrete and deterministic (Cell 1982; Fredrickson 1981). As a racialized social system, all South Africans were forced to have a clear understanding of racial hierarchy in both subjective and objective terms.

\subsection{White Supremacy in Contemporary South Africa}

The fall of apartheid ushered in through massive, longstanding protests, rebellions, and external financial pressures (Clark and Worger 2016; Winant 2001), came about in the early 1990s. After the first universal suffrage vote, resulting in the election of the African National Congress's candidate, Nelson Mandela, South Africa quickly became heralded as a democratic, Black/African-political-led nation-state. The new South Africa, as it is so-called, underwent a significant political transformation, with commitments to eradicating racism, changing the racial structure, and promoting racial and economic equity. The transformation included a re-writing of the constitution that encouraged a united South Africa, which was to be achieved through employing non-racialist ideologies. Non-racialism, as an ideology and mandate, is purported as a commitment to end apartheidera ideals of separatism and white racial superiority; however, its implementation included the unintended consequence of colorblindness (see Ansell 2006; Sharp 1998; Whitehead 2012). As such, non-racialism has been critiqued for influencing misguided practices of 
suggesting the decentering of race/racism, which often takes form by emphasizing class inequities instead (see, for example, the Webster and Pampallis 2017 reader).

Although to this day, White South Africans continue to be overrepresented as top earners, graduates, and owners (Horwitz and Jain 2011; Seekings and Nattrass 2005), scholars use evidence on income and other socioeconomic indicators that either show changes in income shares by race or emphasize the greater within-group inequality than across racial group inequality, like that included in the intro to this article. For another example, the Gini coefficient, a measure of inequality, rose from 36 to 50 within the White South African population, from 47 to 66 within the Black South African population, and rose overall in South Africa (Seekings and Nattrass 2005). It also rose for Coloured South Africans-from 51 in 1975 to 56 in 1996-though the number remains in the middle between White and Black South Africans. The rise of within-group inequality among the Black population occupies considerable attention, with debates on whether Black upward mobility can be evidence of success in the new South Africa, even when most Blacks remain poor (Bhorat and van der Westhuizen 2008; BusinessTech 2015).

Given these debates, more is needed to truly understand the new South Africa's racial order-one that factors into its economic but also political and social dynamics of power and prestige, as well as race. This would better reflect racial capitalism as a root cause of contemporary dynamics (Clarno 2017). Notably, racial orders and racial hierarchies represent structures of society that go above and beyond objective economic measures to capture an overall sense of racial group position (Bonilla-Silva 1997; Blumer 1958). I argue one way we can contribute to this debate is by exploring more subjective understandings of racial ideologies, racism, and racial hierarchies through perceptions.

\subsection{Racial Perceptions of White Supremacy in Contemporary South Africa}

Prior to the 1994 election in South Africa, there were no varying claims of the racial hierarchy. In contrast, claims about racial hierarchies in a colorblind, non-racial South Africa are now more varied and boisterous than ever (Neff 2007; Seekings and Nattrass 2005). These perceptions of the racial hierarchy expose relational constructions of race (Zamora 2018) and tailored understandings of group race relations, which can be used as analytical tools to help us understand the ways groups gain meaning in relation to each other (Kim 2004). Exploring perceptions of the racial hierarchy forces us to explore how groups understand their place within the new South Africa and how they see their group position and movement relative to other groups.

One understanding of the contemporary racial hierarchy is the notion that little has changed. For example, in one experimental study, South African Black, White, and Coloured children as young as three years old associated higher value belongings, such as a fancy new car, with higher-status racial groups, which the authors described as White (Olson et al. 2012). In contrast, the lowest status items, such as a shack, belonged to Black South Africans, and the mid-range items, such as a heavily used car, belonged to Coloured people. For another example, a qualitative study of a racially diverse sample of South African workers found that "racial stereotyping still features in ways that construct racial hierarchies of skill, specifically through an illegitimate belief that White people are intellectually, and otherwise, superior to non-White people" (Reuben and Bobat 2014, p. 12).

However, many White South Africans are claiming they are now deprived or disadvantaged in terms of racial positioning. For example, research by Nadine Dolby (2001) on White youth in racially mixed schools in Durban, South Africa, found that they contain racial resentment because they feel they have been unhinged from their position of privilege. Her study additionally reveals how they employ strategies of resentment, such as using fear to preserve Whiteness and resuscitating Whiteness through ties to global networks to hold on to perceptions of power. Black people in South Africa, in contrast to White people, seem to perceive the legacy of apartheid racism as still mattering. In terms of racial attitudes, the Black population feel slighted and believe that affirmative action redress is valid to improve their place in the racial hierarchy. In Graziella Moraes D. 
Silva's (2012) comparative qualitative study, she found that Black South Africans reported a keen understanding of racism in contemporary South Africa and named it as a function of group competition, which they identified as best addressed through laws that punish racial discrimination and social policies of retribution away from white capital.

Although there has yet to be a comprehensive study of Coloureds' perceptions of the racial hierarchy, extant research has detailed their attitudes toward White and Black South Africans, offering some insight into their claims. For instance, Mohamed Adhikari talks extensively about Coloured South Africans' protection of their privilege in his historical work (Adhikari 2005, 2006), and suggests that as a result, Coloured people have relatively positive attitudes towards White South Africans, and definitively more positive than they had towards Black South Africans, rooted in their striving toward Whiteness (see also, Erasmus 2001). In this way, they perceive the Black racial group to occupy a lower position than them within the racial hierarchy. Using qualitative interviews, Kendrick Brown (2000) details some of the factors shaping tensions between Coloured and Black people, including wariness on behalf of Black people of a Coloured racial group that has sided with Whites, and mistrust on behalf of Coloured people that Black people misplace their resentment of white supremacy towards them.

This project contributes to our understanding of race, racism, and white supremacy in contemporary South Africa by asking, how do Coloured South Africans claim their place in the racial hierarchy? Do they hold onto attitudes that support their position of relative privilege? Furthermore, how do they understand white supremacy and white racism as impacting their experiences?

\section{Data/Methods}

The data for this exploration comes from qualitative interviews I conducted with 50 men and women living in Cape Town in 2015 and 2018. Participants were recruited through snowball sampling techniques based on prior established relationships from the author and by working with a South African research assistant embedded in the Cape Town Coloured and Khoisan communities (see Laster Pirtle 2021). The interview questionnaire contained questions about racial identity development, racial identification choices, experiences of racial discrimination, and perceptions of the South African racial hierarchy. Cape Town continues to be a meaningful space for the preservation of Coloured identity (Jackson 2003). My respondents' ages ranged from 18 to 82, with a median age of 36. Of these, $58 \%$ of the sample identified as women, and $42 \%$ as men. There were $18 \%$ of the sample that self-reported their class status to be poor, nearly half of the sample reported workingclass status ( $44 \%$ ), about a quarter middle-class status $(26 \%)$, whereas $6 \%$ reported being upper-middle class. Table 1 shows participant characteristics.

Table 1. Participant Characteristics.

\begin{tabular}{cccc}
\hline Name & Age & Gender & Occupation \\
\hline Nadesh & 18 & Female & Unemployed \\
Lorenzo & 20 & Male & Unemployed \\
Nadira & 20 & Female & Unemployed \\
Michaela & 21 & Female & Unemployed \\
Shana & 21 & Female & Unemployed \\
Rissa & 22 & Female & Student \\
Sheena & 22 & Female & Sales Agent \\
Rai & 23 & Female & Independent Filmmaker; NGO founder \\
Ella & 25 & Female & Sales Agent \\
Lydia & 25 & Female & Writer; Comedian \\
Nala & 26 & Female & Unemployed \\
\hline
\end{tabular}


Table 1. Cont.

\begin{tabular}{|c|c|c|c|}
\hline Name & Age & Gender & Occupation \\
\hline Nadeen & 28 & Female & Independent filmmaker; Afrikaans teacher \\
\hline Pang & 28 & Male & Driver \\
\hline Tazeem & 28 & Female & Artist \\
\hline Fabio & 29 & Male & Unemployed \\
\hline Irene & 29 & Female & Writer; Artist \\
\hline Desiree & 30 & Female & Unemployed \\
\hline Chrissy & 30 & Female & General Manager \\
\hline Mia & 31 & Female & Massage therapist; cook \\
\hline Yasin & 31 & Male & Comedian \\
\hline Cinnamon & 32 & Female & Entrepreneur \\
\hline Moesha & 33 & Female & Call Center Agent \\
\hline Bruce & 34 & Male & Manager \\
\hline Rose & 34 & Female & Certified Midwife \\
\hline Khusi & 35 & Female & Unemployed \\
\hline Prins & 36 & Male & Sales Agent \\
\hline Hanson & 36 & Female & Herbal Doctor \\
\hline Earnest & 36 & Male & Unemployed \\
\hline Korana & 37 & Male & Warehouse worker \\
\hline Mike & 37 & Male & Artist \\
\hline Collins & 38 & Male & Healer \\
\hline $\mathrm{AJ}$ & 38 & Male & Call Center Agent \\
\hline Beatrice & 39 & Female & Community Activist \\
\hline Charlotte & 40 & Female & Unemployed \\
\hline Jermaine & 40 & Male & Copy Editor \\
\hline Glenda & 40 & Female & Administrator \\
\hline Martin & 40 & Male & Carpenter \\
\hline Tasha & 41 & Female & Event Coordinator; artist \\
\hline Eliza & 41 & Female & Filmmaker; Producer \\
\hline Carl & 41 & Male & Bushman Healer \\
\hline Cherry & 43 & female & Print Editor \\
\hline Garret & 45 & Male & Lawyer \\
\hline Emmett & 46 & Male & Artist \\
\hline Charleen & 47 & Female & General Manager \\
\hline Gary & 50 & Male & Unemployed \\
\hline Hudson & 51 & Male & Unemployed \\
\hline Didi & 52 & Male & Professor \\
\hline Darlene & 53 & Female & Language Teacher \\
\hline Afad & 57 & Male & Religious Leader \\
\hline Hamilton & 79 & Male & Factory Worker (retired) \\
\hline Bazel & 82 & Male & Teacher (retired) \\
\hline
\end{tabular}

To capture subjective claims about the racial hierarchy, my research design was informed by interpretivist and phenomenological approaches to human interaction, which both understands that peoples' knowledge about the world is sociologically constructed and that studying peoples' participation in the social world can say something about society (Fanon 1952). This entails taking participants' words as valid for how they see the world and understanding that their perceptions shape their own realities, ${ }^{2}$ and using sociological inquiry to both contextualize and analyze these perceptions. My questions focused on my participants' understanding of the racial hierarchy, their place in it, and how both might have changed after the transition. In probing about the racial hierarchy, I also asked about relationships with other racial groups and their experiences of racism. Therefore, I also utilize a relationality approach that analyzes probes about the racial hierarchy to uncover respondents' relational constructions of race (Zamora 2018) as well as narrative approaches to understanding everyday racism (Essed 1991) in order to gauge how Coloured South Africans make sense of racist experiences. This interpretivist approach has been used to better understand Coloureds' understanding of race in, for example, Zimitri Erasmus's 
work, Race Otherwise (Erasmus 2017). Interviews were transcribed and then analyzed using interpretive coding cycles, working from large themes (i.e., the experience of racism) to smaller themes (i.e., racially discriminatory experience from Whites), allowing for broad trends and nuanced meaning to be showcased.

\section{Findings and Discussion}

Through analyzing the 50 interviews, I found that Coloured respondents perceive white supremacy in post-apartheid South Africa stemming from (a) experiences of structural and interpersonal racism and (b) views of enduring or complicated racial hierarchies that positions Coloured South Africans as subordinated.

\subsection{Experiencing White Supremacy via Structural and Interpersonal Racism}

Older respondents discussed ample examples of structural disadvantage and racism that Coloured South Africans faced during apartheid via white domination supported by white supremacist ideologies. Some examples include being fired from a job because of their race, as Afad, now a 57-year-old Khoisan religious leader, had experienced working under a White Jewish boss in a leather manufacturing warehouse. A handful of respondents had been imprisoned for protesting apartheid and placed in a Coloured only section of the prison, including a father and son pair who were arrested at school for teaching youth about the harms of the system. Another example included the lasting effects of engaging in antiracist protests, such as the chronic pain that impacted Beatrice, a 39-year-old community activist, as a result of the White South African police force's use of rubber bullets and gas in the townships.

When asked about experiences of racism and prejudice in contemporary South Africa, respondents continued to name White South Africans as the perpetrator more than any other group. When sharing their experience of White racism and discrimination, it was often followed up with frustration that it still remains so long after apartheid ended. Michaela, a 21-year-old mother, for instance, retold a story "she will never forget" about when her young child accidentally touched a White woman while shopping, and the woman scoffed, "Don't touch me. I'm gonna get sick". Michaela said that this made her feel angry because she felt the woman was acting as Whites did during apartheid.

Interplays between Structural and Interpersonal Discrimination-I found it hard to disentangle the interplay between systemic racism and racial discrimination over time in South Africa, and therefore will tell two stories of the train to illustrate the connection. In the first, during apartheid, Emmett, a 46-year-old MC, author, and cultural teacher, begins by sharing how he learned he was Coloured: it was when, around age seven, he was stopped attempting to board a train with his lighter skin mom after the conductors realized the darker kids with her were her own. He tells me he actually thought he was White before that point because to him, to be Black was to be poor, and he did not think his family was poor. It was at that moment he learned he was neither; he was Coloured, which meant he couldn't be in the White area of the train, and also because he was Coloured, it meant he was slightly better off than the Black South Africans he perceived as most deprived, representing a relational construction of race (Zamora 2018). A similar event happened with Cherry, a 43-year-old magazine editor who also explained her first memory regarding race was when she was a young girl, maybe six, and she and her mother were running to the train. They nearly missed it and jumped into the first car they could. However, it happened to be a Whites-only cabin, and the conductor scolded them.

She now remembers it being very upsetting and embarrassing, though she said she did not remember this experience until a more recent train ride triggered the emotions and memory. She was riding to work and sat near two older White women. Soon, a younger Black male came and attempted to sit down next to one of the ladies but could barely sit because one of the White women had her large bag on the seat. Cherry, who normally does not stir the pot, was so upset by the White woman's lack of respect for the young man that she spoke up and asked the woman to move her bag. She ended up getting into an 
argument with the women, who claimed they were not racist but that they had a long day and that Cherry was the rude and untrained one. Cherry said she was upset because it took her back to that early memory-where White folks used their power to keep the best things for themselves.

"I said, 'But that's not fair. We've all paid for tickets. Just pick up your bag and put it on your lap.' ... I just couldn't understand why this woman couldn't see that she was being offensive to another human being. I said, 'Ma'am, sorry, but I think you need to check your privilege here.' ... It just brought it back to the day with my mother. You don't have a voice, and there's always this thing about authority coming from a White person while in South Africa. You know?"

During apartheid South Africa, discriminating against Coloured and Black South Africans was systematically allowable because of policies and practices that reinforced white supremacy and white privilege. In post-apartheid South Africa, it is no longer legal in this way, but the systemic legacy remains in practice.

Despite their experiences and perceptions of White privilege, most respondents said they did not treat White people negatively but rather chose not to interact with White people if they do not have to, which actually remains an easy feat in South Africa (Alexander and Tredoux 2010; Miraftab 2012). In effect, racial separateness is still intact, now in a de facto form. For instance, Cinnamon, a 32-year-old college-educated entrepreneur, explained, "you know, my judgment isn't necessarily because you're White. It's more like, has the privilege of being White made you develop a false sense of superiority?" For these respondents, the positioning of White South Africans in the high strata of the racial hierarchy shapes Coloured participants' negative attitudes towards White individuals, but primarily toward White power and privilege more specifically. It also shapes their perceptions of their own position, understanding that White privilege would mean perceived privilege over Coloured people.

\subsection{Perceiving White Supremacy within Constructions of Racial Hierarchies}

Perceiving White South Africans “On Top" - In order to gauge Coloured respondents' understanding of the racial hierarchy in contemporary South Africa, I began by asking about the past. In all of my interviews, each respondent agreed that the racial hierarchy during apartheid could be described as White then Coloured and/or Other then Black. Unsurprisingly, their answers were much more varied for the present. Of my interviews, 20 percent continued to describe the racial hierarchy in the new South Africa as mimicking the old South Africa. However, nearly one-half felt as though both White and Blacks were at the top, and Coloureds were at the bottom. The other descriptions of racial hierarchy included a Black/African-led system and an economic/meritocratic one. ${ }^{3}$ Given this paper's focus on white supremacy, I use this time to highlight how white supremacy plays into Coloureds' perceptions and variation among two poignant perceptions of the hierarchy.

The majority of those who believe White South Africans remain in control of the racial hierarchy decidedly recognized the systemic nature of Whites' power and privilege and how it persists over time. In addition, most respondents who identified White South Africans as having a solidified place at the top of the racial hierarchy harbored negative attitudes towards Whites' position of privilege. Interviews revealed frustration, betrayal, and disgust in Whites South Africans' ability to hoard resources and materials that shaped Coloured peoples' negative attitudes towards them. For instance, Lydia, a 25-year-old writer and comedian, boasted, "Nobody is treated as well as White South Africans in South Africa. ... This place is heaven [for them], and the worst part is White people don't even realize it."

Importantly, many respondents who understood the legacy of white supremacy in shaping contemporary racial hierarchies understood that this critique also implicates Coloured South Africans for their middling position. Put simply by Garret, a 45-yearold trained but non-practicing lawyer: "very, very little has changed in that regard because fundamentally, the economical regime in South Africa hasn't changed. Even though the regime has changed, the economical regime hasn't changed." Garret, who calls Coloured people brown 
people, puts them in the middle "because of the fact that Black people for such a long period of time, were, like, totally left behind or out of the picture." Yasin, a 31-year-old writer and comedian, also clearly articulated the relative privilege compared to Whites and the relative disadvantage compared to Blacks that brown South Africans experience as being attached to the past:

"It's such a thing where we're still treated better than Black people. The system is still in. There're still White people, Coloured people, and Black people. I say brown, but, yeah. That is still the system. We're still treated better than, but at the same time we're also just seen as not White."

Yasin and others often cited some loose form of population statistics to back their claim, rejecting the idea that a token or small proportion of Black individuals' success means that Blacks as a whole are doing better.

Their own self-awareness of their privilege allows them to see Whites' privilege even more vividly. For instance, when talking about Whites' position of power, Lydia explains, "It's just when you have a leg up, it just makes such a massive difference," but she sees herself as Coloured and middle-class in this too. She retold about how she dropped out of college and had to pack shelves. She said some people would have been stuck there forever, but she had a middle-class family to fall back on and allowed this setback to be temporary. It is important to note that the majority of respondents (but not all) who did see the permanence of white privilege were, like Lydia, self-described as middle or upper class. These are more likely respondents who have entrance into privileged white spaces, such as university campuses and corporations, where they can see the privilege and resources play out and experience some of these same privileges and resources.

Rose, a 34-year-old certified midwife, led by saying the Black South African racial redress policies instituted now don't seem to do what they say, that "although there is a Black economic empowerment and all that, White people still come out on top." She said, for Coloured and Black people, though, it depended on the educational background and was hard to distinguish; "I mean, at the end of the day, the majority of Coloureds are living in poverty; the majority of Blacks are living in poverty." This perspective more so sees the racial hierarchy as being White verse all else, and therefore softly sideswipes the historical relative privilege that Coloured South Africans had, while recognizing those that White South Africans had. On the one hand, this suggests that the striving toward Whiteness (Adhikari 2006), or an eagerness to protect their proximity to Whites, that prior research has found did not resonate with those I spoke to. That is not to say it does not exist amongst some, but it was not a prevailing sentiment among my interviewees. On the other hand, the interviews did reveal an interesting trend of holding perceptions that do not account for relative privilege.

(Not) Perceiving Relative Privilege and Positioning-When probing about racial hierarchies and their relative components, it was interesting to find that often the comparisons the Coloured respondents made were to the Black racial group. Black South Africans were perceived to have the most upward mobility and therefore are sometimes blamed for the Coloured group's perceived downward trajectory. That is, amongst respondents who envisioned the racial hierarchy as Coloureds at the bottom, there was a significant perception of Black people stepping over Coloured people to get jobs, education, better housing, and more. In many ways, this attitude among some of my respondents reflects the strategies of resentment that Dolby (2001) found in her analysis of White South Africans' perceptions of being unhinged from positions of privilege. Many ask, as Nala, an unemployed 26-year-old did, "How do they get it, right?" And come to the answer as she also did that it is, "because of the color of their skin. And that's the downfall of everything".

Adding on to Brown's (2000) finding of fear from Black retaliation among Stevens's (1998) writing on the racial threat between the groups, is my finding that some Colouredidentified respondents perceive a form of reverse racism that disadvantages them. However, rather than focus on interpersonal tension from both groups "on the bottom," I argue that these perceived threats represent a lingering result of white supremacist ideologies crafted during apartheid. As applied here, if Coloured people harbor perceptions of 
being unhinged from their position of past relative privilege, white supremacist ideologies that shaped the form of the racial hierarchy during apartheid still factor into individuals' assessment of contemporary racial orders. Cinnamon adds to this nuance, arguing that Black South Africans' dismissal of Coloureds claims of disadvantage is rooted in their own assessments of not having experienced the same amount of deprivation, "they assume that if you were supposedly so-called Coloured that you were less disadvantaged," to which she disagrees.

In contrast to those who perceive-and likely witness white privilege-the majority (but not all) of respondents who perceive Black advantage self-reported to be poor or working-class, and many of them experienced unemployment. Unsurprisingly, their experience of economic insecurity influences feelings of scarcity and loss. Unlike their more affluent Coloured counterparts, more economically deprived respondents probably interact less with White South Africans on the day-to-day, or if they do, it might be in a service role. They are, however, likely to interact with Black Africans in these same roles. In addition, these respondents confront the reality of increasing Black African upward economic and political mobility compared to stagnation within their own group, which does seem to impact Coloured South Africans' perceptions of relative loss in the new South Africa. These factors help explain why Coloured South Africans construct relational understandings in greater frequency to their Black rather than White counterparts.

Yasin interestingly adds to these relative comparisons describing his perceptions of Black South Africans' ideas about Coloureds: "it's the thing of where I'm in Black people's spaces. It's not mistreatment, it's that thing of I'm not included. I can't say. They might still see it as, "You're not one of us." Yasin understood some of the roots of the Black-Coloured tensions and was not upset by Black folks' weariness because he recognized ways that Coloured South Africans were still treated better. Lydia, a comedian friend of Yasin's, felt similarly and explained:

"I feel like the negative treatment I've received from Black people is more of a defense mechanism because of the antiBlack that's within my community. I've always been very understanding of that 'cause we are antiBlack, and we as Coloureds and sometimes extremely racists and treat Blacks poorly, so I don't blame any Black person for being like, "Fuck Coloured people." I understand that."

For a good number of Coloured respondents, then, Black peoples' upward movement, and even their perceived step over them, is justified. This is one reason why Coloured respondents did not have as negative attitudes towards Black people despite their perceptions of them creating privilege over them. In fact, quite a few respondents did recognize their own learned bias in shaping their relational constructions of Blackness. For instance, Glenda, a forty-year-old office administrator, explained, "we were taught that Black, being Black is not good. It's better to be White, because they're nice... Blacks are dark and so on. And this, we got a lot of that from older people".

Respondents did share experiences of interpersonal prejudice and microaggressions from Black South Africans, such as feeling excluded or demeaned. However, I did not find one example of a major experience of racial discrimination, given its backing by power, that occurred at the hands of a Black person described by any participant, as they had illustrated was done by White perpetrators. The negative experiences and/or exclusion can still incite harm to those on the receiving end and can shape perceptions of tension between groups, but the limited frequency and severity likely factor into a deeper understanding of the white supremacist roots of tensions between non-White groups by some participants.

\section{Conclusions}

Contemporary discussions of racism in South Africa are limited for the ways they hyper-focus on economic structures and change (e.g., Seekings and Nattrass 2005; Webster and Mawbey 2017) and Black and White South Africans' perspectives. My focus on Coloured South Africans' perceptions of racial hierarchy and racism moves past the mere search of evidence for racial hierarchies/enduring racism and moves us toward the 
important but often neglected question, "why do claims about the racial hierarchy matter?" (see, Song 2004). Claims about racial hierarchy matter because they force us to identify the differences between objective and perceived forms of the racial hierarchy, which then allow us to examine how individuals shape meaning around their position within the hierarchy. Overall, the perceptions of racial hierarchy and racism from Coloured South Africans' perspectives are informative about racial tensions between White, Black, and Coloured people in the new South Africa.

In analyzing a sample of Coloured South Africans' views on racism and racial hierarchy, I find that, on the whole, they perceive white supremacy as real and enduring. This is evident through their (a) experiences with interpersonal and systemic racial discrimination, (b) perceptions of White South Africans as still coming out on top, and also (c) perceptions that reject relative privilege and understand Coloured South Africans as uniquely disadvantaged. Moreover, the analysis revealed that Coloured respondents believe that White South Africans harbor privilege and have used their power to hold down and devalue the Coloured group. They mentioned the lack of structural, economic, and political leverage in the new South Africa, and many rejected the mere idea of "racial progress" or a harmonious "rainbow nation" precisely because of the neglect of their own group. In this way, I find similar constructions of racism that Silva (2012) found for Black South Africans of Coloured South Africans.

However, many respondents also perceived Coloureds' position to be unique in its deprivation given the Black power structure. I find the majority of Coloured South Africans perceive themselves as the most deprived group in South Africa because they see nonexistent or blocked economic and other opportunities due to their race, and mostly in comparison to Blacks. This finding supports research that suggests subjective perceptions of racial hierarchies do not always map unto objective ones (e.g., Song 2004) and that racial resentment might go beyond White South Africans (Dolby 2001). The racial resentment and continued racial threat among Black and Coloured groups (Brown 2000; Stevens 1998) has implications for stalling collective action in terms of coalitions toward fully dismantling systemic racism.

Despite variation in perceptions of the racial hierarchy-of White or Black South Africans as better than Coloured South Africans-it is essential to highlight how white supremacy influences both understandings. On the one hand, structural racism is a culprit in lingering, statistically evidenced economic disadvantage of non-Whites in South Africa and of maintained privilege among White South Africans. At the same time, white supremacy may still be the culprit for perceptions of the racial hierarchy that are incongruent with these objective measures, given how the ideology teaches separatism and superiority. Moreover, I contend that white supremacist ideology "colours" perceptions in ways that complicate a shared understanding of racial orders in contemporary South Africa by making it so that some Coloureds do not see their relative privilege. White supremacy is therefore working as designed to hinder anti-racist and solidarity projects. This is because white supremacist ideologies support the sustaining of systemic racism in economic power structures, divisiveness among groups of color, and colorblind/non-racialist attitudes that dismiss those things and diminish the ability to address them.

The focus on Coloured South Africans' voices is purposeful and needed (see also, Adhikari 2005; Erasmus 2017). Still, a comparison of subjective understandings across racial status would better bolster what we know about understandings and rejections of white supremacy today. Innovative experimental methods like that of Olson et al. (2012) could be beneficial, as would qualitative approaches such as focus groups. In addition, findings could be more generalizable by sampling respondents across space, given the particular dynamics of Cape Town. Finally, a more systematic analysis across age cohorts might be particularly constructive.

Nonetheless, this work is telling about broader race relations and racial hierarchies in contemporary South Africa. It demonstrates that the non-racialist and colorblind push to decenter discussions of race contradicts how South Africans see race and racism still 
mattering (see also Ansell 2006; Modiri 2012; Sharp 1998; Whitehead 2012). Rather, white supremacy in South Africa and globally remains a harmful, divisive racial ideology that permeates understandings and perceptions as well as life outcomes. In this way, conversations should continue to emphasize racial capitalism or the interlocking nature of racist and capitalist systems in South Africa and not one over the other (Clarno 2017; Magubane 1979), as well as subjective understandings of racial orders (e.g., Blumer 1958; Kim 2004; Song 2004; Zamora 2018). To truly dismantle the apartheid past, scholars and activists alike must account for all perspectives, including those of mixed-race and middling racial groups, and work to get all persons to better understand the harm of white supremacist racial ideologies.

Funding: This research was funded Hellman Foundation Award 2015-2016, University of California Merced Faculty Senate Award 2015, and Ford Foundation Postdoctoral Award 2018-2019.

Institutional Review Board Statement: The research was approved by Institutional Review Board of University of California, Merced \#15-0016 on 24 June 2015, and was validated by the Centre for Social Science Research at the University of Cape Town (UCT).

Informed Consent Statement: Informed consent was obtained from all subjects involved in the study.

Data Availability Statement: The data is protected as described by the IRB and not publicly available.

Acknowledgments: I appreciate the thoughtful feedback I received presenting early forms of this work to various audiences. I am grateful for the helpful suggestions from anonymous reviewers at Social Sciences and special issue editors David Brunsma and Jennifer Sims. I thank Bradley Van Sitters for research assistance and the University of Cape Town, Centre for Social Science Research for their support. Continued immense gratitude goes to my participants for sharing their important perspectives.

Conflicts of Interest: The author declares no conflict of interest.

\section{Notes}

1 Black, as a label, is sometimes used in contemporary scholarship for both South Africans who would have been considered Black or African during apartheid, and for those who would have been labeled as Coloured. The inclusion of Coloured within the Black category is consistent with language in legislation (e.g., The Black Economic Empowerment Act) and stems from Black Consciousness. However, given the purpose of this paper, I use "Black" to signify Black Africans as an identifier for the former group and Coloured as a separate identifier for the latter group. The larger project (see Laster Pirtle 2021) from this work explores the variation among Coloured racial identities, highlighting why some who have a Coloured ancestry do not choose this label themselves for its negative association with the apartheid state (and some do identify as Black). In the findings section, I use the labels respondents themselves use.

2 This standpoint is influenced by what is known as the Thomas Theorem (Thomas and Thomas 1928, p. 572), which argues that if situations are perceived as real, they are at least real in their consequences.

3 About a sixth of respondents rejected the perception that a strict racial hierarchy continued to operate at all within contemporary South Africa. It was not that a hierarchy ceased to exist-they conceived that higher strata incurred the most desirability, power, and resources-but they did not perceive racial divisions as aligning with the divisions in the hierarchy. Most of the responses here point to economic class as the category to separate groups. The argument is that there are classes of rich and poor within each racial group, and therefore there is not a similar racial hierarchy that perfectly correlates with class as it had during apartheid.

\section{References}

Adhikari, Mohamed. 2005. Not White Enough, Not Black Enough: Racial Identity in the South African Coloured Community. Athens: Ohio University Press.

Adhikari, Mohamed. 2006. Hope, Fear, Shame, Frustration: Continuity and Change in the Expression of Coloured Identity in White Supremacist South Africa, 1910-1994. Journal of Southern African Studies 32: 467-87. [CrossRef]

Alexander, Lameez, and Colin Tredoux. 2010. The Spaces between Us: A Spatial Analysis of Informal Segregation at a South African University. Journal of Social Issues 66: 367-86. [CrossRef]

Ansell, Amy. 2006. Casting a Blind Eye: The Ironic Consequences of Color-Blindness in South Africa and the United States. Critical Sociology 32: 333-56. [CrossRef]

Bestman, Michael. 2009. We Are the Original Inhabitants of this Land: Khoe-San Identity in Post-Apartheid South Africa. In Burdened by Race: Coloured Identities in Southern Africa. Edited by Mohamed Adhikari. Cape Town: UCT Press, pp. $134-54$. 
Bhorat, Haroon, and Carlene van der Westhuizen. 2008. Economic Growth, Poverty and Inequality in South Africa: The First Decade of Democracy. Development Policy Research Unit Conference 5: 27-29.

Blumer, Herbert G. 1958. Race Prejudice as a Sense of Group Position. The Pacific Sociological Review 1: 3-7. [CrossRef]

Bonacich, Edna. 1973. A Theory of Middleman Minorities. American Sociological Review 38: 583-94. [CrossRef]

Bonilla-Silva, Eduardo. 1997. Rethinking Racism: Toward a Structural Interpretation. American Sociological Review 62: 465-80. [CrossRef]

Brown, Kendrick. 2000. Coloured and Black Relations in South Africa: The Burden of Racial Hierarchy. Macalester International 9: 198-207.

BusinessTech. 2015. White vs. Black Unemployment in South Africa. August 27. Available online: https://businesstech.co.za/news / trending/96887/white-vs-black-unemployment-in-south-africa/ (accessed on 28 January 2022).

Cell, John W. 1982. The Highest Stage of White Supremacy: The Origins of Segregation in South Africa and the American South. New York: Cambridge University Press.

Clark, Nancy L., and William H. Worger. 2016. South Africa: The Rise and Fall of Apartheid. New York: Routledge.

Clarno, Andy. 2017. Neoliberal Apartheid: Palestine/Israel and South Africa after 1994. Chicago: The University of Chicago Press.

Dolby, Nadine. 2001. White Fright: The Politics of White Youth Identity in South Africa. British Journal of Sociology of Education 22: 5-17. [CrossRef]

Erasmus, Zimitri. 2001. Introduction: Re-Imagining Coloured Identities in Post-Apartheid South Africa. In Coloured by History, Shaped by Place: New Perspectives on Coloured Identities in Cape Town. Edited by Zimitri Erasmus. Cape Town, South Africa: Kwela Books, pp. 1-27.

Erasmus, Zimitri. 2017. Race Otherwise: Forging a New Humanism for South Africa. New York: NYU Press.

Essed, Philomena. 1991. Understanding Everyday Racism: An Interdisciplinary Theory. Newbury Park: Sage Publications, vol. 2.

Fanon, Frantz. 1952. Black Skin, White Masks. Translated by Charles Lam Markmann. New York: Grove Press.

Fredrickson, George M. 1981. White Supremacy: A Comparative Study in American and South African History. New York: Oxford University Press.

Horwitz, Frank M., and Harish Jain. 2011. An assessment of Employment Equity and Broad Based Black Economic Empowerment in South Africa. Equality, Diversity and Inclusion: An International Journal 30: 297-317. [CrossRef]

Jackson, Shannon. 2003. Being and Belonging: Space and Identity in Cape Town. Anthropology and Humanism 28: 61-84. [CrossRef]

Kim, Claire Jean. 2004. Imagining Race and Nation in Multiculturalist America. Ethnic and Racial Studies 27: 987-1005. [CrossRef]

Laster Pirtle, Whitney N. 2021. 'Able to identify with anything': Racial identity choices among 'coloureds' as shaped by the South African racial state. Identities, 1-19. [CrossRef]

Lewis, Gavin. 1987. Between the Wire and the Wall: A History of South African Coloured Politics. New York: St Martin's Press.

MacDonald, Michael. 2006. Why Race Matters in South Africa. Cambridge: Harvard University Press.

Magubane, Bernard. 1979. The Political Economy of Race and Class in South Africa. New York: Monthly Review Press.

Marx, Anthony W. 1998. Making Race and Nation: A Comparison of the United States, South Africa, and Brazil. New York: Cambridge University Press.

Miraftab, Faranak. 2012. Colonial Present: Legacies of the Past in Contemporary Urban Practices in Cape Town, South Africa. Journal of Planning History 11: 283-307. [CrossRef]

Modiri, Joel. 2012. The Colour of Law, Power and Knowledge: Introducing Critical Race Theory in (Post-) Apartheid South Africa. South African Journal on Human Rights 28: 405-36. [CrossRef]

Nattrass, Nicoli, and Jeremy Seekings. 2001. Two Nations? Race and Economic Inequality in South Africa Today. Daedalus 130: 45-70.

Neff, Daniel F. 2007. Subjective Well-Being, Poverty and Ethnicity in South Africa: Insights from an Exploratory Analysis. Social Indicators Research 80: 313-41. [CrossRef]

Olson, Kristina R., Kristin Shutts, Katherine D. Kinzler, and Kara G. Weisman. 2012. Children Associate Racial Groups with Wealth: Evidence from South Africa. Child Development 83: 1884-99. [CrossRef]

Reuben, Shanya, and Shaida Bobat. 2014. Constructing Racial Hierarchies of Skill-Experiencing Affirmative Action in a South African Organisation: A Qualitative Review. SA Journal of Industrial Psychology 40: 1-12. [CrossRef]

Seekings, Jeremy, and Nicoli Nattrass. 2005. Class, Race, and Inequality in South Africa. New Haven: Yale University Press.

Sharp, John. 1998. 'Non-racialism'and its discontents: A post-apartheid paradox. International Social Science Journal 50: $243-52$. [CrossRef]

Silva, Graziella Moraes D. 2012. Folk Conceptualizations of Racism and Antiracism in Brazil and South Africa. Ethnic and Racial Studies 35: 506-22. [CrossRef]

Song, Miri. 2004. Introduction: Who's at the Bottom? Examining Claims about Racial Hierarchy. Ethnic and Racial Studies 27: 859-77.

Stevens, Garth. 1998. 'Racialised' Discourses: Understanding Perceptions of Threat in Post-Apartheid South Africa. South African Journal of Psychology 28: 204-14. [CrossRef]

Thomas, William I., and Dorothy Swaine Thomas. 1928. The Child in America: Behavior Problems and Programs. New York: Knopf.

van der Berge, Pierre. 1967. Race and Racism: A Comparative Perspective. New York: Wiley.

Webster, Edward, and John Mawbey. 2017. Revisiting the National Question. In Unresolved National Question in South Africa: Left Thought under Apartheid and Beyond. Edited by Edward Webster and Karin Pampallis. Johannesburg: Wits University Press, pp. 1-18. 
Webster, Edward, and Karin Pampallis. 2017. Unresolved National Question in South Africa: Left Thought under Apartheid and Beyond. Johannesburg: Wits University Press.

Whitehead, Kevin. 2012. Racial Category Membership as Resource and Constrain in Everyday Interactions: Implications for Racialism and Non-Racialism in Post-Apartheid South Africa. Ethnic and Racial Studies 35: 1248-65. [CrossRef]

Winant, Howard. 2001. The World Is A Ghetto: Race And Democracy Since World War II. New York: Basic Books.

Zamora, Sylvia. 2018. Mexican Illegality, Black Citizenship, and White Power: Immigrant Perceptions of the U.S. Socioracial Hierarchy. Journal of Ethnic and Migration Studies 44: 1897-914. [CrossRef] 